\title{
АНАЛІЗ ТА ПРОФІЛАКТИКА ЕКСПЕРТНИХ ПОМИЛОК, ВИНИКАЮЧИХ ПІД ЧАС ПРОВЕДЕННЯ ТРАСОЛОГІЧНОЇ ЕКСПЕРТИЗИ МЕХАНІЧНОГО ПОШКОДЖЕННЯ ОДЯГУ
}

\begin{abstract}
Анотація. За визначенням Р.С. Белкина, експертна помилка це судження експерта або його дія, яка не відповідае об'єктивній дійсності, що не призводить до мети експертного дослідження, що е результатом сумлінної помилки [1]. У зв’язку з цим важливою задачею експертних підрозділів е повний та всебічний аналіз зібраних та наданих на дослідження речових доказів. У найзагальнішому плані метою трасологічного дослідження, механічного пошкодження одягу, як і будь-яких інших криміналістичних досліджень, являеться встановлення доказової бази або фактичних даних події, які мають доказове значення. У зв'язку з цим отримати вищезазначену інформацію можливо шляхом вивчення матеріальних об'єктів із застосуванням спеціальних знань та методів, у галузі трасологічного дослідження. Спеціальні пізнання експертів порою допомагають слідству та суду у винесенні об’єтивних та неупереджених рішень. В даній статті розглянуті недоліки при складанні судово-трасологічних висновків експерта, зокрема при дослідженні пошкоджених деталей одягу. Одяг, як об’єкт трасологічного дослідження, несе на своїй поверхні дуже важливу інформацію, оскільки є первинним джерелом дії ушкоджуючих фактів. Чітке розмежування помилок, має сприяти повному та обгрунтованому дослідженню, а вірно підібрані профілактичні дії унеможливлюють їх подальше виникнення. В експертній практиці останнім часом поширюеться дослідження пошкоджених деталей одягу і тому необхідно звернуту увагу на експертні помилки, які можуть бути допущені експертом під час проведення даного виду дослідження.
\end{abstract}

Ключові слова: експертна помилка, трасологічна експертиза, пошкодження одягу, висновок експерта.

Anosov Igor, Solyanik Volodymyr Kharkiv Scientific Research Forensic Center of the Ministry of Internal Affairs of Ukraine

\section{ANALYSIS AND PREVENTION OF EXPERT ERRORS OCCURRING DURING TRASSOLOGICAL EXAMINATION OF MECHANICAL DAMAGE TO CLOTHES}

Summary. According to Belkin R.S., an expert error is an expert's judgment or action that does not correspond to objective reality, which does not lead to the purpose of expert research, which is the result of a conscientious error [1]. In this regard, an important task of expert departments is a complete and comprehensive analysis of the material evidence collected and provided for research. In the most general plan, the purpose of trasological research, mechanical damage to clothing, as well as any other forensic research, is to establish the evidence base or factual data of the event that have probative value. In this regard, the above information can be obtained by studying material objects using special knowledge and methods in the field of trasological research. Special knowledge of experts helps the investigation and the court in making objective and impartial decisions. This article considers the shortcomings in the preparation of forensic and trasological conclusions of the expert, in particular in the study of damaged details of clothes. Clothing, as an object of tracological research, carries on its surface very important information, as it is the primary source of the action of damaging facts. Clear delimitation of errors should contribute to a complete and reasonable study, and correctly selected preventive actions make it impossible for them to occur further. The work draws attention to the most common shortcomings in expert practice, in the production of traceological examinations of mechanical damage to clothing and not only. It can be assumed that taking into account the expert errors and critical remarks contained in the work will help the experts and heads of expert subdivisions who are engaged in this type of research in the future to more fully, clearly and comprehensively reflect the results of their research in the conclusions of the ship's expert and formulate reasoned conclusions on the expertise. In expert practice, the study of damaged items of clothing has recently become widespread, and therefore it is necessary to pay attention to expert mistakes that may be made by an expert during this type of study.

Keywords: expert error, trasological examination, damage to clothing, expert opinion.

$\Pi$ остановка проблеми. Принципами судово-експертної діяльності являються законність, незалежність, об'єктивність і повнота дослідження [2]. Для досягнення та вирішення поставлених задач експерт повинен забезпечити достовірність висновку, своєчасно розпізнати та попередити виникнення експертних помилок.

В словниках під «помилкою» визначають «неправильність в діях і думках», але в юриспруденщії є різноманітні поняття терміну «помилка», но всі вони схожі в одному, що помилка, це фрактор від якого залежить доля подальшого судового рішення.

Також слід зауважити, що сучасний вітчизняний ринок активно поповнюеться різноманітним асортиментом швейного виробництва. Застосовуються нові технології, нові текстильні волокна та нитки. Тому при проведенні зазначеного виду експертиз виникають труднощі пов'язані з недостатньою роз-

${ }^{1}$ ORCID: https://orcid.org/0000-0001-6266-208 
робленістю методики, методів і засобів, які перевірені наукою та апробовані практикою [3, с. 2].

Наслідки помилок необхідно розглядати з різноманітних боків, це можуть додаткові затрати труда та часу по усуненню виявленої помилки, збільшення терміну досудового розслідування, наявність риску покарання невинної особи, а саме основне та недопустиме, це фрормування думки про некомпетентність експертів та взагалі правоохоронної системи.

Отже, для розв'язання завдань криміналістичного дослідження пошкоджених деталей одягу та недопущення експертних помилок, експертові необхідно знати не тільки морфологічні ознаки кожного виду механічного пошкодження предметів одягу, а розуміти алгоритм дослідження наданих об'єктів, послідовність їх опису, визначення та зазначення пошкоджень (потертостей, особливостей носіння), встановлення матеріалу одягу, властивостей даного матеріалу та інше. Даний об'ем інформації допоможе експертові у формуванні об'єктивного, повного дослідження та в подальшому уникнення експертних помилок.

Аналіз останніх досліджень і публікацій. В трасології питання дослідження пошкоджених частин одягу розглядається з загальної точки зору і помилкам, які виникають, під час дослідження даних об'єктів приділяється дуже мало уваги.

У роботі Н.П. Майлис розгадається дуже великий обсяг інформащї стосовно судової трасології, розглядаються загальнотеоретичні та методологічні основи трасології, сучасні науково-практичні аспекти методики дослідження слідів і об'єктів судово-трасологічної експертизи, методичні і організаційні питання трасологічної експертизи за всіма їі видами [4, с. 133].

B pоботах P.C. Белкина [5] запропоноване більш розширене поняття експертної помилки, де автор визначає іï якості невідповідності дійсності судження експерта або його дій, що не приводить до мети дослідження, якщо спотворене судження або невірна дія являє собою процес добровільної помилки.

Узагальнюючи експертну практику слід зауважити, що виникненню експертних помилок сприяє не тільки особа, яка проводить дослідження, а також незадовільне відношення до своїх службових обов'язків ініціатора призначення висновку експерта. Це полягає у непрофресіоналізмі, малограмотності відносно юридичних пізнань, а саме в системи криміналістики, що проявляеться в некоректному поставленні питань, невірному отриманню порівняльних зразків та інше.

Згідно 3 аналізу експертних помилок, який наведений в роботах A.I. Винбергтон, Р.С. Белкиним, Н.П. Майлис, Я.М. Каплуновим встановлено, що висновки судових експертів повторюються одні й ті ж помилки, що вказуе на неуважне ставлення деяких експертів та керівників експертнихпідрозділівдопроцесу формування висновку.

Виділення не вирішених раніше частин загальної проблеми. У сучасному світі в період розвитку інформаційних та технічних технологій не слід забувати і про дотримання демократичних принципів правосуддя, рівність громадян перед законом та забезпечення захист інтересів суспільства та кожного громадянина окремо. Це понукае на створення нових шляхів вирішення різноманітних проблем і зокрема, проблему експертної помилки, яка може переродитися в судову помилку. Тільки вірно виконане у повному обсязі з дотриманням всіх методик та відповідаючи дійсності експертне дослідження (висновок експерта) повинно бути основою судочинства.

Проблемою, яка виникае під час виконання дослідження пошкоджених частин одягу є відсутність методичних рекомендащій та наявність ілюстративного матеріалу, який й би у повному обсязі міг показати загальні та особливі ознаки пошкоджень. Також слід зауважити, що деякі співробітники не бажають самостійно шукати літературу за даним напрямком дослідження, а використовують раніше виконані висновки експертів, з усіма недоліками та можливо помилками.

Тому питання експертної помилки під час виконання трасологічної експертизи механічного пошкоджених одягу повинне розглядатися всебічно з зазначенням помилок та шляхами їх вирішення.

Мета статті $є$ висвітлювання експертних помилок, які можуть виникнути під час дослідження пошкоджених деталей одягу та рекомендації, що до їх усунення. Надання ілюстративного матеріалу з поясненнями та списку літератури, який може статися в пригоді під час виконання даного виду дослідження.

Виклад основного матеріалу. Взагалі експертну помилку можна визначити, як діяльність експерта, яка не відповідає дійсності, яка тягне за собою викривлені судження та невірні дії, що становлять собою результат сумлінної омани. Але даний фракт слід відрізняти від завідома неправдивого висновку експерта, який визначається в свідомому ігноруванні, замовчуванні та викривленні суттєвих фрактів об'єктів дослідження, а також невірному оцінюванню отриманих даних.

По своїй суті експертні помилки можна розділити на три види: помилки процесуального характеру, які виражаються в порушенні експертом процесуальних норм законодавства (вихід експерта за межі своєї компетенції, недостатньо мотивовані висновки, недостатній об'єм проведеного дослідження та інше); гносеологічні помилки, які допускаються при пізнані сутності, властивостей та ознак об'єктів, підсумків експертного дослідження та їх інтерпретації; діяльні помилки, які виникають під час здійснення експертом дій з об'єктами дослідження. При фрормуванні висновку експерта необхідно враховувати всі вищезазначені помилки та виключити їх появлення.

До найбільш розповсюдженої помилки слід віднести помилку, яка виникає під час дії 3 об'єктами дослідження. Результатом таких помилок можуть бути об'єктивні та суб'єктивні факти. Надати вичерпаний перелік обєєтивних та суб'єктивних експертних помилок не $є$ можливим, з причини різноманітності об'єктів дослідження, що веде до різноманітності експертних помилок, в кожному конкретному випадку.

3 метою уникнення експертних помилок, слід звернути увагу експерта на найбільш поширені недоліки, які можуть виникнути під час проведення висновку експерта. 
Експертні помилки об’ективного характеру: відсутність методики, або методичних рекомендацій; використання несправного вимірювального приладу; використання приладів 3 недостатньою роздільною здатністю.

Експертні помилки суб’ективного характеру залежать від самого експерта, як суб'єкта який здійснюе дослідження, тому мають різноманітні факти їх допущення.

Професійна некомпетентність експерта, вона може виражається в незнанні сучасних методик, невмінні використанні певних технічних засобів дослідження або використовувати методи. Професійна некомпетентність експерта може проявлятися і під час спроби вирішення їм питань, які відноситься до іншої області спеціальних пізнань, а не до тіеї, якими він володіе.

Професійне упущення експерта це недбалість, поверхневе дослідження, зневага до методик та методичних рекомендацій та інше.

Також до помилок суб'єктивного характеру можна віднести дефекти органів почуття експерта, невпевненість у своїх знаннях, мала досвідченості, зневажливе ставлення до думки колег, відсутність логіки та дефекти організації та планування експертного дослідження.

У процесі дослідження пошкоджених деталей одягу виникнення експертних помилок, може статися вже під час розв'язання завдань поставлених перед експертом. Для уникнення подальшої проблеми слід звернути увагу, ініціатора призначення дослідження, на питання, які потрібно розв'язати експертові, тому що невизначеність питань, може привести до двоякого толкування та повести дослідження у іншому напрямку.

Експертові, під час опису упаковки та об’єктів дослідження, необхідно звернути увагу на її цілісність, можливість втручання до її вмісту, кількості наданих об’ектів їх найменуванні та стану, що при подальшому дослідженні може пояснити ті чи інші особливості об'єкта, виявленні під час проведення висновку, а також уникнення розбіжностей з матеріалами справи, які можуть привести до призначення додаткових, а інколи повторних висновків експерта.

Невірно підготовлений об'єкт дуже ускладнюе, а в деяких випадках ставить за неможливе проведення експертного дослідження.

До найбільш поширених помилок, при упакуванні одягу та деталей одягу, слід віднести: відсутність заходів захисту пошкоджених частин; невірно упакований одяг; неправильне упакування одягу (упакування вологого одягу або невірно просушеного); недосить надійна упаковка та інше.

У разі виникненні питань стосовно поставлених переде експертом завдань, упаковки об'єктів дослідження, цілісності упаковки, кількості об'єктів, найменуванні об'єктів та інше, слід звернутися до ініціатора призначення з клопотанням о роз'яснені проблеми, що виникла.

Отже не слід самостійно домислювати питання та виправляти необачність допущену ініціатором призначення експертизи, тому що слідча помилка іноді ставить за неможливе виконання висновку експерта у повному обсязі, що в свою чергу може привести до перегляду справи і навіть судових помилок. Експерт повинен заявляти клопотання о наданні додаткових матеріалів, якісних зразках, відомостей про спосіб зберігання об’єктів дослідження, а також уникати виходу за межі своєї компетенщії під час виконання висновку.

Під час опису огляду не слід забувати, що особливості одягу визначаються матеріалом тканини всіх її деталей, природою волокна, характером зав'язків волокон в нитях та нитей в тканині. Одяг, на відміну від м'яких тканин тіла людини, здатний відображати і довгий час зберігати ознаки слідового контакту, що дуже важливо для процесів ідентифікації і діагностики [6, с. 13].

Опис об'ектів наданих на дослідження повинен проводиться повно з урахуванням всіх виявлених особливостей, матеріалу, способу плетення, розмірних характеристик, кольору, наявності застібок, карманів, підкладок. При опису об’ектів слід мати на увазі, що трикотаж це текстильний матеріал структуру якого становлять з'єднані між собою петлі (рис. 1, 2).

Тканиною є текстильне волокно, виготовлене переплетенням взаємно перпендикулярних систем ниток, складається з двох перпендикулярних систем ниток. Систему ниток, що йдуть уздовж тканини, називають основою, а систему ниток, розташованих поперек- утком, відповідно нитки називають основними і уточними (рис. $3-5$ ).

Виходячи з вищесказаного необхідно зазначити, що при опису об’ектів дослідження слід уникати таких словосполучень, як форма переплетення краще казати вид або тип переплетення та трикотажна тканина, яке можна замінити на трикотажне полотно, вироби з трикотажного матеріалу та інше.

Експерт під час опису об’ектів дослідження повинен звернути увагу на ступень зношеності, наявності латок, самостійних швів та інші. Всі виявлені та вивчені особливості і ознаки в подальшому
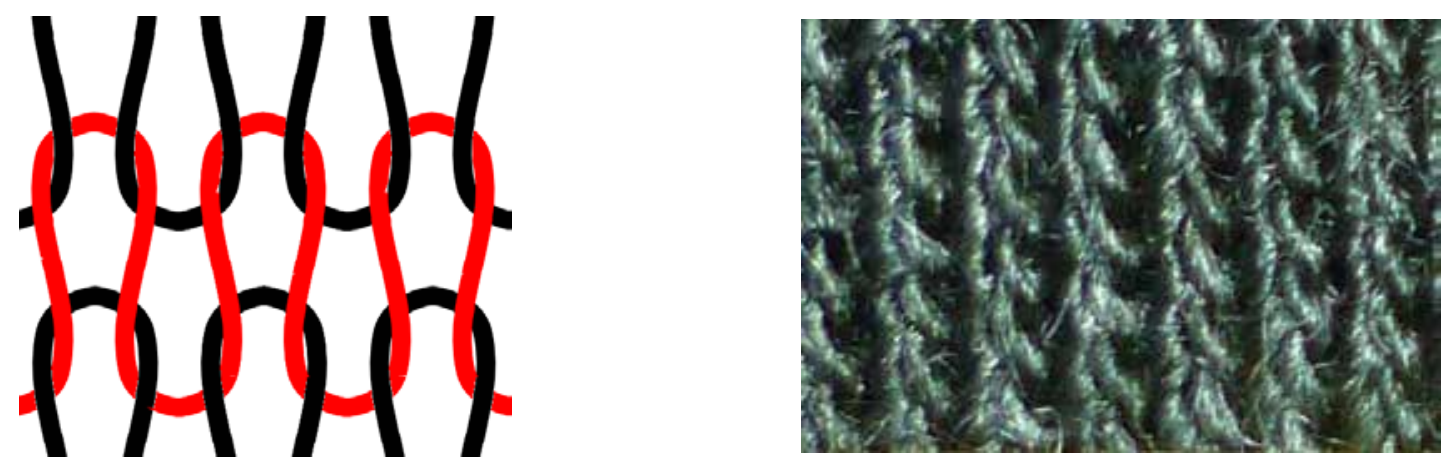

Рис. 1, 2. Структура найпростішого трикотажу 



Рис. 3, 4. Структура тканини

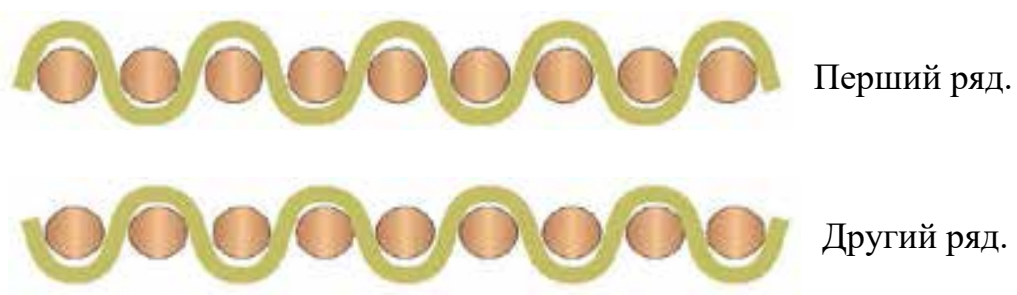

Рис. 5. Система ниток та рух нитки утка

можуть служити для повного та об'єктивного дослідження та уникнення експертних помилок.

Не слід забувати і про розмірні характеристики самих об'єктів дослідження та виявлених ушкоджень, встановлення розмірних характеристик зручно проводити м'якою сантиметровою стрічкою і бажано на манекені. Порівняння величин відстаней, отриманих при вимірюванні предметів одягу на манекені, і предметів, розкладених на столі, показуе, що різниця між ними досягае 3 см (на манекені, як і на тілі, відстані виявляються більшими) [7, с. 19].

У процесі слідоутворення одяг та деталі одягу виступають в якості слідосприймаючого об'єкта, тому містять інформацію про слідоутворюючий об'єкт, а саме про фракт та фрорму контакту, напрямок та силу взаємодії, механізм та умови пошкодження. При нанесенні ушкоджень ріжучим, колючим, колючо-ріжучим та рубящим знаряддям, ознаки ушкоджень характеризують механізм їх утворення і містять обмежену інфрормацію про особливості будови слідоутворюючого об’екта. Тому уважний огляд об'єктів, зі сторони експерта, полегшить подальший висновок про механізм пошкодження. Також слід звернути увагу експерта на забруднення, які можуть бути на одязі і в разі необхідності залучити спеціалістів інших видів експертиз.

Зазначаються найменування предмета одягу, матеріал, з якого він виготовлений і його будова, його розміри, ступінь зносу, наявність або відсутність забруднень, розривів, розрізів, пошкоджень від термічного або хімічного впливу та інші особливості, які мають значення для вирішення поставлених питань [8, с. 204].

На стадії роздільного дослідження судовим експертом проводиться всебічне і повне вивчення властивостей та ознак досліджуваних об'єктів, явищ, процесів [9].

Найбільш поширеними помилками під час дослідження одягу є невірний опис одягу та його деталей, огляд проводиться поверхнево, не враховуються викривлені ознаки, які утворені під час слідоутворення, не враховуеться наявність підкладки, складок та інше. Виявлені ознаки оглядаються частково, що може привести до втрачання існуючих особливостей пошкодженої ділянки, та іноді ставить за неможливе проведення дослідження у повному обсязі.

Багато питань виникае у експерта під час встановлення механізму пошкодження одягу. Для повного та всебічного дослідження необхідно ретельно вивчити поверхню самого пошкодження, поверхню вільних кінців ниток, а також при можливості торцеву поверхню волокон у нитках. В роботі С.Д. Кустановича [7] наведені відмінності різноманітних механічних пошкоджень 3 приведеними зображеннями та схемами, що дозволяє експертові зорієнтуватися у встановленні механізму пошкодження.

При дослідженні наскрізних пошкоджень необхідно звернути увагу на краї пошкоджень, a саме на розташування вільних кінців ниток в краях пошкоджень. Розташування ниток на різному рівні, краї ниток бархатисті, волокна нитей розтягнуті ці ознаки вказують, що пошкодження створене шляхом розриву (рис. 6,7 ).

При розрізах краї ниток рівні та розташовані на одному рівні, волокна ниток також рівні в деяких випадках приплющені, це залежить від інструменту, яким скоєно розріз, а також від форми клинка (рис. 8).

Слід мати на увазі, що при розрізах, нанесених ножем 3 негострим лезом можуть виникнути своєрідні комбіновані ушкодження, одна частина яких є розрізами, а інша - розривами [7, с. 32].

Пошкодження нанесені ножицями розрізняються за своїм характером в залежності від гостроти їх бранш. Розріз нанесений гострими ножицями має лінійну форму та рівні краї ниток в поперечному зрізі. Розріз нанесений ножицями 3 негострими браншами, має ступінчатий характер, нитки витягнуті, іноді волокна ниток спресовані, для наочності наведено збілышене зображення тканини з гумової ниткою, які перерізані ножицями з браншами різ- 


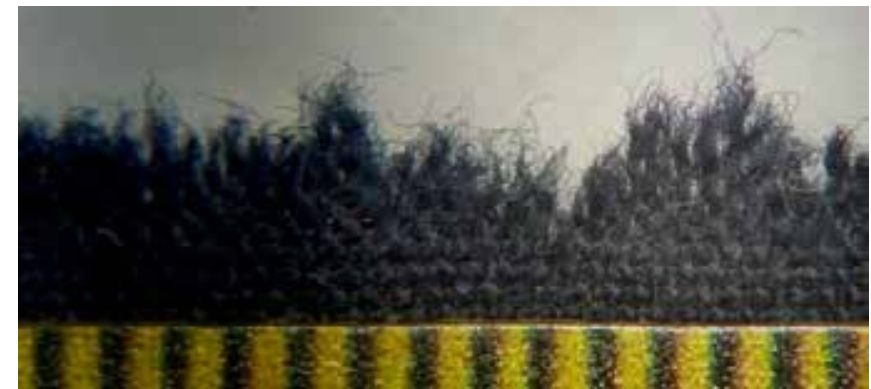

Рис. 6. Збільшене зображення кінців ниток при розриві

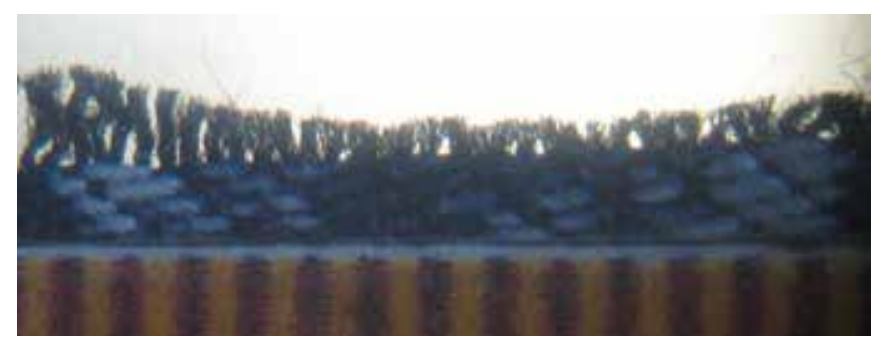

Рис. 8. Збільшене зображення кінців ниток при розрізі

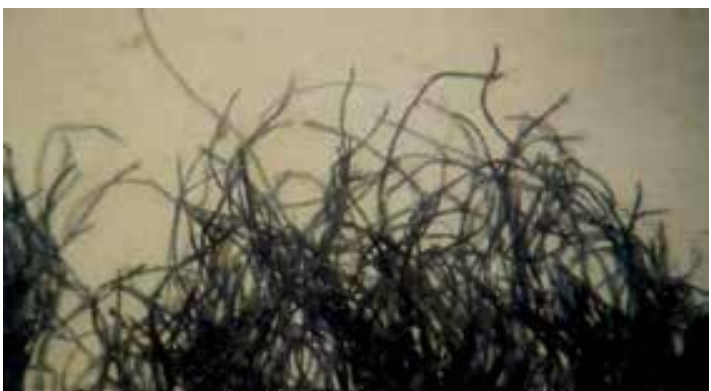

Рис. 7. Збільшене зображення потоншених волокон ниток при розриві

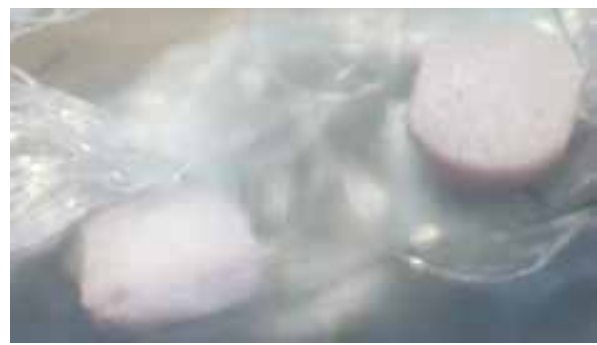

Рис. 9. Збільшене зображення гумової нитки при розрізі ножицями ної частоти загостреності, де можна побачити приплюснуті волокна та рівний зріз волокон (рис. 9).

Для уникнення експертних помилок під час підсумку та аналізу виявлених ознак механічного пошкодження одягу та його деталей, експерт повинен пам'ятати, наступне:

- гладкий зріз волокна нитки, без деформації є характерною ознакою ріжучої дії;

- витонченість характерна для розривів; сплющеність, зігнутість та деформація це ознака розсічення;

- потертість, задирки на волокнах ниток $є$ ознакою дії обуха клинка;

- краї пошкодження грубі, кінці пересічених ниток розволокнені та сплющені, лінія поділу не є прямою, дані ознаки характерні для розрубів, але також слід враховувати гостроту леза сокири.

Закінчивши аналіз, синтезують результати вивчення індивідуальних ознак, визначають їх якісне значення в цілому та у сукупності, dpopмулюють висновок про достатність (або недостатність) індивідуальних ознак для ідентифікаційного дослідження [10, с. 12].

Однією із обов'язкових стадій проведення трасологічної експертизи механічного пошкодження одягу та його деталей є експертний експеримент. На стадії експертного експерименту судовий експерт установлює механізм слідоутворення, взаємодію певних частин механізмів - об'єктів дослідження, виявляє причинний зв'язок між певними явищами та процесами, отримує зразки для порівняльного дослідження [9].

Метою експертного експерименту можуть бути либо перевірка експертної гіпотези о механізме нанесення пошкодження, либо отримання зразків для порівняння, либо те й інше [11, с. 29].

Під час проведення експертного експерименту необхідно вірно встановити загальні умови експертного експерименту, а саме: утворення експериментальних слідів в умовах близьких до досліджуваних; отримання експериментальних слідів на матеріалах аналогічних досліджуваному; не однократність утворення слідів; утворення експериментальних слідів знаряддям наданим на дослідження; застосовування методів, які мінімізують пошкодження досліджуваних об'єктів.

Кропіткою роботою експертного експерименту є виявлення та врахування змінюваності експериментальних слідів, утворених під впливом певних фрактів, щоб уникнути експертних помилок необхідно аналізувати отримані експериментальні сліди, а також коригувати дані зразки та змінювати умови експерименту, до тих пір поки не буде результату близького до досліджуваного (наданого на дослідження), або експерт переконається у неможливості отримання таких ушкоджень.

Порівняння загальних та окремих ознак повинно проводиться одним або кількома способами: зіставлення, накладення, суміщення. Великі труднощі можуть виникнути, в ході проведення такої стадії висновку експерта, як порівняльне дослідження. Труднощі проведення порівняльного дослідження з'являються під час виявлення співпадінь або відмінностей ознак порівняльних об'єктів між собою. Під час проведення порівняльного дослідження необхідно проводити співпадіння тільки 3 аналогічними ознаками, експерт у ряді випадків порівнюе ознаки, які апріорі різноманітні, так пряме відображення порівнюеться з дзеркальним, лінійній слід з точковим та інше.

Встановлення збігу загальних ознак дає змогу зробити висновок про їх родову, видову, групову належність; у разі збігу загальних та індивідуальних ознак (особливостей) фрормуеться висновок про тотожність [10, с. 14].

Помилкою $є$ форомування проміжного висновку даної стадії лише констатацією збігів або відмінностей, експертові необхідно провести обгрунтований опис стадії оцінки виявлених ознак, на яких відбувається підсумковий результат по- 
рівняльного дослідження, довести в результаті яких дій утворилися відмінності ознак та в якій мірі виявлені відмінності можуть вплинути на тотожність порівнювальних зразків.

Підсумовуючі результати проведених експертних досліджень експертові необхідно здійснити комплексну ощнку всіх отриманих значень, визначити стійкість та індивідуальність виявлених ознак, науково обгрунтувати їх походження, а також виявлені збіги або розбіжності. Щоб уникнути експертних помилок експерт повинен зайвий раз перевірити хід та результати проведеного їм дослідження, на всіх стадіях висновку експерта, проводити дослідження згідно 3 діючими методиками, літературними джерелами та унеможливити виникнення двоякого толкування отриманих результатів.

Під час офрормлення результатів висновку експерта, щоб уникнути зайвих питань, необхідно дотримуватися наступних правил: в тексті висновку слід уникати використання вузько спрямованих термінів, отримані результаті повинні бути проаналізовані, детально пояснені, аргументовано доведені, висновок складаеться стислим та містить конкретні відповіді на конкретні питання. Формулювання у висновках повинні бути чіткими, ясними, зрозумілими й конкретними, та не допускати двоякого тлумачення [4, с. 140].

На стадії оформлення результатів проведеного експертного дослідження судовим експертом: виготовляеться ілюстративний або додатковий матеріал, який додається до складеного висновку (додатки до висновку) [9].

Ілюстращії, креслення, графріки, діаграми, фоотознімки, потрібно розташовувати після тексту, де вони вперше згадуються або на наступній сторінці. Ілюстративний матеріал може оформлятися додатком до висновку експерта. Посилання на ілюстрації повинні розміщуватися в тесті висновку.

При офрормленні ілюстративного матеріалу, експертові необхідно звернути увагу на наступні особливості: зображення повинно бути чітким та контрастним, необхідно уникати розпливчатості поділу масштабної лінійки, бирки 3 пояснювальними написами повинні бути читабельні. Не слід забувати і про упаковку в якій об’єкти дослідження надані, невідповідальність упаковки може привести до повного знищення або руйнування досліджуваних об'єктів. Детальні зображення пошкоджених ділянок одягу повинні бути чіткими з відображенням всіх виявлених ознак, які характерні для даного виду пошкодження. Особливу увагу слід приділить пояснювальним написам, текст повинен бути стислим, але як можна чітко характеризувати відображений знімок.

Додатки є невід'ємна частина висновку експерта і від змісту та якості додатків порою залежить встановлення істини судового процесу.

Висновки і пропозиції. У роботі приведений стислий огляд основних проблем, з якими може зіткнутися експерт, під час проведення судово-трасологічної експертизи механічного пошкодження одягу. Розглянуті стадії проведення висновку експерта 3 наведеними найбільш поширеними експертними помилками та наведені шляхи їх уникнення.

Аналізуючи вищевикладене слід звернути увагу на основні профілактичні засоби, які необхідно застосовувати в експертній практиці, для уникнення експертних помилок. В процесі призначення висновку експерта необхідно звернуту увагу ініціатора на речі, які у подальшому можуть привести до двоякого тлумачення відповідей і навіть неможливості подальшого дослідження. До таких речей слід віднести некоректно поставлені питання, невірно зібрані зразки, надання зразків яких недостатньо для відповіді на поставлені питанні та інше. Для уникнення даної проблеми необхідно проводити кваліфріковані консультащії, заняття, створювати вузько спрямовані методичні рекомендації, по різноманітним напрямкам призначення судових експертиз.

Значний вплив на уникнення експертних помилок надає створення нових, сучасних методик та методичних рекомендацій, які грунтуються на досягненнях науково-технічного прогресу та високочутливих приладах. Впровадження нових методів дослідження дає змогу провести декілька досліджень, в рамках однієї експертизи та підтвердити або спростувати отриманий результат.

Але, основним та невід'ємним кроком у попередження експертних помилок $є$ перевірка висновків експертів, керівниками експертних установ та більш кваліфрікованими експертами. Усвідомлення виконавця о майбутній перевірці, понукає до постійного контролю своїх досліджень та приведення додаткових аргументів на користь свого рішення. Перевірка висновків експерта повинна проводитися у самій експертній установі та бути ретельно і добре організованою.

\section{Список літератури:}

1. Белкин Р.С. Криминалистическая энциклопедия. Москва, 1997. 157 с.

2. Про судову експертизу : Закон України від 25 лютого1994 р. № 4038-ХII / Верховна Рада України. URL: https://zakon.rada.gov.ua/laws/show/4038-12

3. Сухарев А.Г., Калякин А.В., Егоров А.Г., Головченко А.И. Трасология и трасологическая экспертиза : учебник. Саратовский юридический институт МВД России, 2010. С. 341-342.

4. Чернов В.Г., Аносов I.В., Бурда В.А. Особливості експертного дослідження різаних пошкоджень одягу. Вісник криміналістичної асоціацї̈ України. Харків : ХНУВС, 2019. С. 131-142.

5. Белкин Р.С. Криминалистика: проблемы, тенденции перспективы. От теории к практике. Москва, 1998.83 с.

6. Киселевич И. В. Криминалистические исследования механических повреждений одежды и ее следов в расследовании преступлений : автореф. дис. на соискание уч. степени канд. юрид. наук : 12.00 .09 «уголовный процесс; криминалистика и судебная экспертиза; оперативно-розыскная деятельность». Москва, 2008. 30 с.

7. Кустанович С.Д. Исследование повреждений одежды в судебно-медицинской практике. Москва : «Медицина», 1965. $217 \mathrm{c}$.

8. Кантор И.В. Трасология и трасологическая экспертиза. Москва : ВА ИМЦ ГУК МВД России, 2002.376 с.

9. Про затвердження Інструкції з організації проведення та оформлення експертних проваджень у підрозділах Експертної служби Міністерства внутрішніх справ України : затв. наказом М-ва внутр. справ України від 17.07.2017 № 591. Ст. 2254. URL: https://zakon.rada.gov.ua/laws/show/z1024-17 
10. Коструб А.М., Грищенко О.В., Щирба Д.Є., Чашницька Т.Г. Методика встановлення цілого за частинами. Експертна спеціальність 4.2. «Дослідження знарядь, агрегатів, інструментів і залишених ними слідів, ідентифікація цілого за частинами». Київ : ДНДЕКЦ МВС України, 2015. 37 с.

11. Салимов X. Научные основы и методика экспермента при производстве трасологических експертиз. Душанбе, 1967. 218 c.

\section{References:}

1. Belkin R.S. (1997) Kriminalisticheskaya entsiklopediya [Forensic encyclopedia]. Moscow. (in Russian)

2. The Law of Ukraine (February 25, 1994) Pro sudovu ekspertyzu [On Judicial Examination]. № 4038-XII. Kyiv: Verkhovna Rada of Ukraine. Available at: https://zakon.rada.gov.ua/laws/show/ru/4038-12 (in Ukrainian)

3. Sukharev A.G., Kaliakin A.V., Egorov A.G., Golovchenko A.I. (2010) Trasologiia i trasologicheskaia ekspertiza [Trasology and trasological examination]. Saratovskii iuridicheskii institutt MVD Rossii. (in Russian)

4. Chernov V.H. Anosov I.V. Burda V.A. (2019) Osoblivosti yekspertnogo doslidzhennya rizanikh poshkodzhen' odyagu [Features of expert research of cut damages of clothes]. Visnyk Kryminalistychnoi Asotsiatsii Ukrainy. Kharkiv: Kharkyvskyi nacional'nyj universytet vnutrishnih sprav. (in Ukrainian)

5. Belkin R.S. (1998) Kriminalistika: Problemyi, tendentsii perspektivyi. Ot teorii k praktike [Forensic science: Problems, prospect trends. From theory to practice]. Moscow. (in Russian)

6. Kiselevich I.V. (2008) Kriminalisticheskie issledovanija mehanicheskih povrezhdenij odezhdy i ee sledov v rassledovanii prestuplenij [Forensic investigations of mechanical damage to clothing and its traces in the investigation of crimes]: avtoref. dis. kand. jurid. nauk, Moskovskii universitet MVD Rossii. (in Russian)

7. Kustanovich S.D. (1965) Issledovanie povrezhdeniy odezhdyi v sudebno-meditsinskoy praktike [Investigation of damage to clothing in forensic practice]. Moscow: «Medicine». (in Russian)

8. Kantor Y.V. (2002) Trasologiya i trasologicheskaya ekspertiza [Trasology and Trasological Expertise]. Moscow: VA IMTs GUK MVD Rossii. (in Russian)

9. Pro zatverdzhennya Instruktsii $\mathrm{z}$ organizatsii provedennya ta oformlennya yekspertnikh provadzhen' $u$ pidrozdilakh Yekspertnoi sluzhbi Ministerstva vnutrishnikh sprav Ukraïni [On approval of the Instruction on the organization and execution of expert proceedings in the departments of the Expert Service of the Ministry of Internal Affairs of Ukraine]: nakaz Ministerstva vnutrishnih sprav Ukrai'ny [Decree of the Ministry of Internal Affairs of Ukraine] vid 17.07.2017 № 591, zarejestrovano v Ministerstvi justycii' Ukrai'ny 18 serpnja 2017 r. za № 1024/30892. Available at: https://zakon.rada.gov.ua/laws/show/z1024-17 (in Ukrainian)

10. Kostrub A.M., Hryshchenko O.V., Shchyrba D.I., Chashnytska T.H. (2015) Metodika vstanovlennya tsilogo za chastinami. Yekspertna spetsial'nist' 4.2. «Doslidzhennya znaryad', agregativ, instrumentiv i zalishenikh nimi slidiv, identifikatsiya tsilogo za chastinamI» [The technique of establishing the whole behind the parts. Expert specialty 4.2. "The precedent flag, aggregates, tools and the ones they left behind, the complete identification of the parts"]. Kyiv: Derzhavnyi naukovo-doslidnyi ekspertno-kryminalistychnyi tsentr mynysterstva vnutrishnykh sprav Ukrainy. (in Ukrainian)

11. Salimov H. (1967). Nauchnyie osnovyi i metodika ekspermenta pri proizvodstve trasologicheskih ekspertiz [Scientific bases and methods of expertise in the production of traceological examinations]. Dushanbe. (in Russian) 